\title{
Transdziedzinowość - retoryczność - cyfryzacja. W stronę tekstów transdziedzinowych i eksplozji strukturalnej
}

\begin{abstract}
Szczęsna Ewa, Transdziedzinowość - retoryczność - cyfryzacja. W stronę tekstów transdziedzinowych i eksplozji strukturalnej [Transdisciplinarity - rhetoric - digitization. Towards trans-domain texts and a structural explosion]. „Przestrzenie Teorii” 34. Poznań 2020, Adam Mickiewicz University Press, pp. 223-244. ISSN 1644-6763. DOI 10.14746/pt.2020.34.10.

The article analyses the agency of transgression and transcendence at the domain level. It characterizes the specificity of this process and points to factors that influence its intensification (especially the development of digital technologies). The text presents the effects of this process - the impact on the way cultural texts and their structures exist. The article examines the rhetorical dimension of a trans-disciplinary nature, the effect of which is the creation of trans-disciplinary texts. It proves the thesis that in the interaction between disciplines a structural explosion takes place, which leads to the creation of new textual figures and structures and the formation of new types of texts. These issues are illustrated using specific examples of trans-disciplinary texts.
\end{abstract}

KEYWORDS: transdisciplinarity, rhetoric, digitization, transgression culture, digital art, comparative studies

Żadna dziedzina nie może rozwijać się w pełni, gdy jest izolowana od pozostałych. Ta prosta konstatacja wynika z faktu, że motorem napędowym rozwoju kultury często było umieszczanie jej tekstów, zjawisk, wreszcie dziedzin w nowych konfiguracjach myślenia i działania, które wytrącając je z przestrzeni uznanej za rozpoznana, czyniły na nowo nieprzezroczystymi, zwracały uwagę na niedostrzeżone dotąd aspekty, stawiały nowe pytania i domagały się udzielenia na nie odpowiedzi. Konfiguracje te aktywizowały ruch transgresji i transcendencji, konfrontowania zjawisk i tworzenia nowych jakości w procesie wzajemnego dopełniania się elementów, ich przekształcania i rekontekstualizowania. Zdolność tego ruchu do inicjowania nowych znaczeń, ale też bytów i zdarzeń kultury jest dyspozycją retoryczna, która dodatkowo znajdowała swoją reprezentację w samym nazewnictwie - w pojęciach interdziedzinowości i transdziedzinowości. Same te kategorie sa wielkimi figurami - organizuje je bowiem myślenie porównawcze i metaforyczne, których motorem są transgresja 
i transcendencja ${ }^{1}$, mające swe reprezentacje w różnych dziedzinach (np. geologii, psychologii, filozofii, genetyce, religii).

Obecna w kulturze i coraz bardziej wyraźna intensyfikacja procesu zacierania granic między wytworami kultury oraz wyprowadzanie go z poziomu tekstu, gatunku na poziom dziedzin każe postawić pytanie o czynniki, które ten proces kształtuja, o jego istotę, ale też o jego skutki dla tekstualności, zastanych dziedzin i myślenia o dziedzinowości - dla sposobu istnienia form ekspresji kulturowej.

\section{Inter-, trans- jako prefiksy różnej relacyjności. $U$ podstaw transcendencji dziedzin}

Za istotne dla retorycznego wymiaru transcendencji/transgresji dziedzinowości/dyscyplinarności wydaje się rozróżnienie między przedrostkami inter-, trans- ${ }^{2}$. W procesie inter- do głosu dochodzą dwie dziedziny (często też reprezentujące je teksty), które wchodzą we wzajemne relacje na tych samych prawach, zachowując swoją osobność. Inter- akcentuje ruch „ku

${ }^{1} \mathrm{~W}$ myśleniu o transgresji zdaje się dominować niemal fizykalny akt przekraczania granic; w myśleniu o transcendencji - istnienie poza, które również wiązane jest z wyjściem poza granice, zacieraniem ich, a nawet znoszeniem.

${ }^{2}$ Przyjmuję rozgraniczenie znaczeniowe tych przedrostków dokonane w odniesieniu do kategorii inter-/transsemiotyczności oraz inter-/transmedialności w badaniach nad relacjami, w jakie w procesie kształtowania znaczeń tekstowych wchodzą ze sobą systemy semiotyczne i systemy medialne w przekazach polisemiotycznych i multimedialnych. Zob. E. Szczęsna, Poetyka mediów. Polisemiotyczność, digitalizacja, reklama, Warszawa 2007, s. 29-31. Przeprowadzone tam rozróżnienie, w intencji autorki uniwersalizujące oba przedrostki, wskazuje na możliwość ich użycia w analogiczny sposób w odniesieniu do innych kategorii - dyskursu, dyscypliny, dziedziny. Warto tu podkreślić, że o swoistej uniwersalności obu prefiksów świadczy ich obecność w nazewnictwie odnoszącym się do różnych poziomów badań (w badaniach tekstologicznych, badaniach form gatunkowych, dyskursów, badaniach dyscyplinowych i dziedzinowych). Zob. B. Nicolescu, Transdisciplinarity - Past, Present, and Future, [w:] Moving Worldviews - Reshaping Sciences, Policies and Practices for Endogenous Sustainable Development, red. B. Haverkort, C. Reijntjes, Leusden 2007, s. 142-166, <http://basarab-nicolescu. fr/Docs_articles/TRANSDISCIPLINARITY-PAST-PRESENT-AND-FUTURE.pdf> [dostęp: 3.02.2021]; I. Domańska, Antropologia literatury - projekt interdyscyplinarny czy transdyscyplinarny, „Przegląd Kulturoznawczy” 2011, nr 1, s. 55-64; A. Zeidler-Janiszewska, Visual Culture Studies czy antropologicznie zorientowana Bildwissenschaft? O kierunkach zwrotu ikonicznego w naukach o kulturze, „Teksty Drugie” 2005, nr 4, s. 9-29. Badacze podkreślaja, że stosowanie prefiksów wpisuje się we współczesną tendencję nauk humanistycznych do pobudzania wyobraźni poznawczej na drodze kreowania nazw, nieustannego odnawiania słownika, lokowania teorii w sferze eksperymentu. Zob. np. D. Ulicka, Sub-, pre-, post-, inter-, czyli jak formy prefiksalne graja w teatrze literaturoznawczej mowy?, [w:] Przyszłość polonistyki. Koncepcje - rewizje - przemiany, red. A. Dziadek, K. Kłosiński, F. Mazurkiewicz, Katowice 2013, s. 473-488; R. Nycz, Możliwa historia literatury, „Teksty Drugie” 2011, nr 1-2. 
sobie", transcendencję własności, cech dziedzin, która pozwala na taką interakcję dziedzin, w której tworzą one dla siebie nawzajem kontekst interpretacyjny. Jest to ruch, w którym konfrontowane elementy dziedzin epitetyzują i reinterpretuja je tylko w procesie wprawiania ich w interakcję. Dziedziny jednak zachowują swoją odrębność, niezależność, jednocześnie zapisując w swej pamięci ślad tych procesów.

Inaczej jest w przypadku transdziedzinowości, gdzie ruch oznacza istotną ingerencję w niezależność dziedziny. Jest to ruch transgresji - wyjścia poza własne granice i swobodnego przenikania w rejony jednej lub wielu dziedzin. W wyniku tego ruchu zatarciu ulega granica między dziedzinami, mniej wyrazista staje się osobność dziedzin. Sposób istnienia przedmiotów tych dziedzin, tekstowe myślenie o nich zmieniaja się tak, że coraz trudniej jest jednoznacznie przypisać je do określonej dziedziny, zwłaszcza gdy każda traci swoją niezależność na rzecz wzajemnej sieci powiązań z innymi. Mieszanie czy „skotłowanie form”, o którym pisał Clifford Geertz, odnosząc je do nasilających się, związanych z demokratyzacją życia społecznego strategii tekstowych, dokonuje się na poziomie dziedzin. Akt transgresji na trwałe modyfikuje dotychczasową ontyczność elementów poddanych działaniu trans- i ustanawia nową jakość.

Zarówno ruch „trans-”, jak i relacja „inter-” reprezentują tendencję do przekraczania (a w przypadku trans- wręcz znoszenia) zastanych granic, która jest jedną z dwóch tyleż przeciwstawnych, co uzupełniających się tendencji rządzących dyskursywnością. Tą druga jest skłonność do ustanawiania granic i rozgraniczania. Wynika ona z potrzeby porządkownia, ale też oddzielania tego, co „ja” (i co moje) od tego, co „nie ja” (i co cudze). Wyznaczone granice daja $\mathrm{w}$ danym momencie odczucie uporzadkowania rzeczy, oddzielenia bytów różnych, niepasujących do siebie. Dlatego rozgraniczenie i granice zawsze podkreślają inność, osobność tego, co „ja” oraz tego, co „nie ja”.

Równolegle jednak z potrzebą rozgraniczania uruchamiana jest potrzeba poznawania tego, co inne, przenikania w jego rejony; doświadczenia nieznanego, tego, co poza granicą - potrzeba wynikająca z ciekawości poznawczej. Jeśli rozgraniczanie staje na drodze tym tendencjom, przestaje być wyłącznie aktem porządkowania, a staje się aktem przemocy. Podobnie z aktem

${ }^{3}$ C. Geertz, O gatunkach zmaconych (Nowe konfiguracje myśli społecznej), przeł. Z. Łapiński, [w:] Postmodernizm. Antologia przekładów, red. R. Nycz, Kraków 1997, s. 215. Warto podkreślić, że tendencje w naukach społecznych i humanistyce, ukazywane przez Geertza jako aberracje, dziś lokują się w przestrzeni normy. Geertz pisze: „W czasach, gdy przedstawiciele nauk społecznych szczebioczą o aktorze, scenie, intrydze, widowisku i postaciach scenicznych, humaniści zaś mruczą coś o motywacji, władzy, perswazji, wymianie społecznej i hierarchii, granica między obu grupami [...] w gruncie rzeczy się zaciera" (tamże, s. 229).

225 Transdziedzinowość - retoryczność - cyfryzacja 
przemocy mamy do czynienia wówczas, gdy przekraczanie granic, prowadząc do ich zniesienia, stawia opór ich konstytuowaniu się. Nieustanne napięcie, jakie powstaje między obu tendencjami, ma charakter retoryczny - tworzy dogodne pole do wytworzenia nowych jakości w przestrzeni dziedzin.

Oba prefiksy inter- i trans- implikuja procesualność - nazywają zjawiska ruchu. W odniesieniu do dziedzin oba przedrostki wskazują na oddziaływanie. W pierwszym przypadku zmiana dokonuje się na drodze modyfikowania cech elementów wchodzących w interakcję - wzajemnego oddziaływania na siebie zderzanych dziedzin (i reprezentujących je tekstów) przy jednoczesnym zachowaniu ich ontycznej niezależności. W drugim przypadku ruch zmiany jest ruchem odkształcania, ingerowania jednej dziedziny w drugą tak, że dochodzi do uzyskania nowej jakości. Dziedziny tracą dotychczasową osobność i niezależność - każda przesycona jest cechami innej i nimi uwarunkowana. W obszarze literaturoznawstwa obie te tendencje współistnieja, dochodząc do głosu naprzemiennie z różnym nasileniem i w różnym czasie - wraz z pojawiającymi się tendencjami i modami badawczymi. Tak jest w przypadku poznawania komparatystycznego rozciagającego się od porównawczego zestawiania literatury i innych form artystycznych, czym rządzi figura wielkiego porównania aż do postawy hermeneutycznej, korzystającej z myślenia metaforycznego, w którym jedne teksty postrzegane są w kontekście innych, a ich rozumienie kształtowane jest w procesie przenikania się pól znaczeniowych. Tak jest też w przypadku badań teoretycznoliterackich angażujących w poznawanie literatury filozofię, socjologię, teorie innych sztuk.

Transdziedzinowość pozostaje w ścisłym związku z transtekstualnościa. Jest to szczególnie widoczne w przestrzeni sztuki, gdzie inspirowana jest ontycznością tekstu jako tworu w swej istocie niestałego. Teksty artystyczne są dziełami w ruchu i to w znaczeniu szerszym niż ujmował to Umberto Eco, ograniczając tę kategorię do utworów o zmieniającej się warstwie przedstawień ${ }^{4}$. Interakcja, w jaką wchodzą po stronie odbiorcy: doświadczenie estetyczne, rozumienie, domniemanie na temat intencji nadawczej, wiedza o tekście, nastawienie odbiorcze modelowane różnodziedzinowym, zmiennym w czasie kontekstem sprawiaja, że warstwa ta za każdym razem jest czymś innym, czy też ukazuje się jako coś innego. Niestałość tekstu sztuki wynika zatem z tego, że jest on również konstruktem mentalnym powstającym w akcie odbioru, dla którego warstwa wyrażania jest źródłem impulsu znaczeniotwórczego.

Jednocześnie konstrukt ten nie jest oderwany od otoczenia społecznego. Wręcz przeciwnie, każdy tekst jako tworzony i doświadczany w przestrzeni

${ }^{4}$ U. Eco, Dzieło otwarte. Forma i nieokreśloność w poetykach wspótczesnych, przeł. L. Eustachiewicz i in., Warszawa 2008, s. 81-86. 
społecznej, zakotwiczony jest i osadzony w różnych dyskursach, mediach, wykreowanych przez człowieka i w nim zakorzenionych (jako że myślimy dyskursami, mediami) ${ }^{5}$. Dyskursy i media tworza kontekst, który jest interakcją społeczno-komunikacyjnego otoczenia i zaangażowania tekstu oraz własności implikowanych przez tekst (są to np. historycznie zmienne cechy gatunku, wielorako uwarunkowanego systemu semiotycznego ${ }^{6}$, kontekst tematyczny, problemowy). Każdy tekst wiąże ze sobą zmienną w czasie tradycję różnych dyskursów, technologii, mediów, które kształtująjego warstwę przedstawień i znaczenie - to jest oddziałuja na to, jak to znaczenie jest konstytuowane przez poznający/kreujacy podmiot. Dlatego ma rację James Robert Martin, gdy potwierdza za Malinowskim wage kontekstu, ale nie ma jej, gdy za etnologiem dodaje, że chodzi o kontekst powstania tekstu, gdy mianowicie pisze: „[...] warto powtórzyć opinie Malinowskiego sprzed ponad pięćdziesięciu lat: nie da się zrozumieć tekstu, jeśli nie wie się nic o kontekście, w którym ten tekst powstał"7.

Problem polega na tym, że bezpośredni dostęp do tego kontekstu nie jest możliwy. Każda wiedza o kontekście powstania tekstu ma charakter zapośredniczony - nie jest kopią momentu powstania tekstu ani doświadczeniem kontekstu, ale wiedzą o nich - tym, co odbiorca wyinterpretowuje z samego tekstu i tekstów mu towarzyszacych. Mamy zatem do czynienia ze zbiorem przekonań - tym, co zostało uznane za istotny kontekst lub czemu odbiorca nadał taką rangę. Tak rozumiany kontekst określić można jako domniemany. Cechą konstytutywną kontekstu domniemanego jest

${ }^{5}$ Przyjmuję rozumienie tekstu, medium wypracowane w: E. Szczęsna, Dyskurs polisemiotyczny i jego środki, [w:] tejże, Poetyka mediów..., s. 14-36, gdzie tekst rozumiany jest jako struktura semiotyczno-semantyczna, wielorako uwarunkowana, charakteryzująca się różnym stopniem złożoności; zaś medium określane jest jako złożony, wieloaspektowy system przekazywania i kreowania treści o charakterze informacyjnym, estetycznym, perswazyjnym, uwarunkowany m.in. technologicznie, semiotycznie, sytuacją nadawczo-odbiorczą. Z kolei dyskurs rozumiany jest tu jako tekst (wypowiedź) w sytuacji społecznego użycia. Jako taki dyskurs ma swój wymiar komunikacyjny, semiotyczny (zwłaszcza językowy), poznawczy, interakcyjny. Zob. Dyskurs jako struktura i proces, red. T.A. van Dijk, przeł. G. Grochowski, Warszawa 2001, s. 9-13.

${ }^{6}$ Ponieważ wychodzę z założenia, że systemy semiotyczne są w sposób konieczny wielorako uwarunkowane, nie istnieją w izolacji od otoczenia społecznego, danej kultury w danym momencie jej rozwoju, wreszcie jednostkowego użytkownika kultury, pozostaję przy kategorii systemu semiotycznego (i konsekwentnie transsemiotyczności, intersemiotyczności, polisemiotyczności), rezygnując w tym miejscu z kategorii modalności (i multimodalności) akcentujacych społeczne i kulturowe uwarunkowanie systemów semiotycznych. Zob. G. Kress, Multimodality. A Social Semiotic Approach to Contemporary Communication, London-New York 2010; G. Kress, T. van Leeuwen, Multimodal Discourse. The Modes and Media of Contemporary Communication, London 2001.

${ }^{7}$ Systemowo-funkcjonalna analiza dyskursu, red. A. Duszak, G. Kowalski, Kraków 2013, s. 16. 
jego zmienność wynikająca z niestałości perspektywy poznawczej, wielowariantywność zakotwiczona $\mathrm{w}$ wielości równoprawnych interpretacji oraz bycie elementem współtworzącym tekst. W procesie interpretacji dochodzi do zmiany kwalifikacji kontekstu, który staje się częścią tekstu. Jako stała zmienna kształtuje niestałość tekstu, jego nieustanną transgresję wyznaczaną przez procesualność kształtujących go czynników lokujących się poza bezpośrednim aktem tworzenia. Zmienność kontekstu sprawia, że każdy tekst jest w istocie transtekste m - bytem, który jest w ciagłym ruchu, który przekracza granice innych tekstów, a tym samym i dyskursów, a także, że sam jest nieustannie wystawiany na ich oddziaływanie. W przypadku gdy stwierdzamy ustalenie/unieruchomienie znaczenia, oznacza to jedynie, że przestało być ono ustanawiane, konteksty uwzględniane, że ustała transcendencja tekstu - że tekst przestał żyć.

Skoro na tekst oddziałuje tak wiele kształtujących go zmiennych, pojawia się pytanie o to, co sprawia, że tekst nie rozpada się. Za trwanie tekstu (a w konsekwencji dziedzin, które one tworza) odpowiedzialna jest siła dośrodkowa - są nią znajdujące się u podstaw każdego tekstu utekstowione, uniwersalne struktury myślenia oraz powtarzalne reguły tworzenia - geny tekstu ${ }^{8}$, ujęte w powtarzalnych strukturach tekstowych. Lokują się one na przeciwnym biegunie sił odśrodkowych, inicjujących transcendencję tych struktur, co przejawia się $\mathrm{w}$ tym, że struktury te maja swoje odmienne reprezentacje w rozmaitych dziedzinach, różnią się pełnioną funkcja, sposobem semiotycznego, medialnego i dyskursywnego istnienia. Obie siły, mające przeciwny zwrot, współistnieją w kulturze, dopełniają się, a nawet wzajemnie reinterpretuja. Sa one gwarantem z jednej strony trwania kultury (siły dośrodkowe), z drugiej jej rozwoju (siły odśrodkowe). Działaja w obrębie tych samych struktur myślenia - kształtując je na użytek raz to jednej, raz to drugiej tendencji.

Efektem działania siły dośrodkowej są istniejące jako jednostki zdefiniowane i ustabilizowane: struktury tekstowe, gatunki, ale też same dziedziny/dyscypliny zaświadczające o stanie kultury i utwierdzające w nim jej użytkowników. Argumentem na rzecz potwierdzenia owej stabilizacji, porządkowania, systemowości są etymologia słowa dyscyplina (łac. 1. nauka: wiedza, wykształcenie, system, metoda; 2 . wychowanie, chów: sposób życia, zasady, porządek, urządzenie, ćwiczenie; ustrój państwa) i jego znaczenia, wśród których znajduja się: karność, rygor, ustalony porządek, a także, dawniej: „krótki bat o kilku rzemieniach służący do wymierzania kary ciele-

${ }^{8}$ Roland Barthes pisze o genotekście - operacjach logicznych właściwych wypowiadającemu się podmiotowi - dziedzinie niejednorodnej - werbalnej i popędowej. Zob. R. Barthes, Teoria tekstu, przeł. A. Milecki, [w:] Wspótczesne teorie badań literackich za granica. Antologia, t. 4, cz. 2, red. H. Markiewicz, Kraków 1996, s. 198. 
snej”'. Z kolei działanie sił odśrodkowych wiązać się będzie z rozsadzaniem ustalonych definicji i destabilizacja - konstrukcjami zaczynającymi się od inter-, trans-, de-, post-. Transdziedzinowość wiąże się zatem bezpośrednio z działaniem sił odśrodkowych, z zakłóceniem ustalonego porządku, byciem w ruchu i twórczym zmąceniem prolongującym to, co nowe.

W uczynieniu dominanta „bycia dziedzin w ruchu” tkwi potencjał retoryczny transdziedzinowości - elementy jednych dziedzin przenikaja w rejony innych, dotychczas postrzeganych jako odrębne, niepasujące do siebie, co prowadzi do tworzenia nowych, często zaskakujących jakości. W nauce staje się to możliwe dzięki zastapieniu paradygmatu naukowego w rozumieniu Thomasa Kuhna - wspólnota podejmowanych przez różne dziedziny zagadnień. Paradygmat rozumiany jako akceptowane w danej nauce osiagnięcia, które dostarczają naukowcom modelowych problemów i rozwiązań ${ }^{10}$; ale też jako model, wzorzec; zbiór zakotwiczonych w empirii pojęć, teorii tworzących podstawę danej nauki stoi na straży dziedzinowości. Zastapienie go problemami, zagadnieniami, które są miejscem wspólnym różnych dziedzin (np. globalizacja, globalne ocieplenie, ekologia, podmiot nieantropocentryczny) umożliwia transdziedzinowość, w której dziedziny wzajemnie się dopełniaja, tworzac rozwiązania komplementarne ${ }^{11}$, a przy tym hybrydyczne. „Można powiedzieć, że w humanistyce pojawiają się coraz to bardziej interesujące hybrydy łączace profesjonalną wiedzę dyscyplinarną ze sztuką traktowana jako medium przekazu tej wiedzy"12 - pisze Ewa Domańska.

Postawa pokornej kontemplacji zastapiona zostaje aktem performatywnym i nastawieniem na sprawczość podmiotu badawczego ${ }^{13}$. Tekst jako przedmiot powolnych badań (np. czytania filologicznego w rozumieniu, jakie

${ }^{9}$ Stownik języka polskiego, red. M. Szymczak, Warszawa 1988, t. 1, s. 487.

${ }^{10}$ Zob. T.S. Kuhn, Struktura rewolucji naukowych, przeł. H. Ostromęcka, Warszawa 2001, s. 10. Według Kuhna pojawiający się brak zgodności badanego przedmiotu z paradygmatem, wskazujący na anomalie w paradygmacie, prowadzi do zmiany paradygmatu, co z kolei jest oznaką rewolucji naukowej (tamże, s. 17). Zob. też T.S. Kuhn, Dwa bieguny, przeł. S. Amsterdamski, Warszawa 1985 (oraz posłowie S. Amsterdamskiego i obecna tam kategoria użycia paradygmatycznego).

${ }^{11}$ Jak pisze Ewa Domańska: „Wysiłki zmierzają zatem w kierunku komplementarności ujęć, wzajemnego uzupełniania się i dopełniania badań. Dlatego też być może zasadne byłoby obecnie miast na podejścia inter- czy transdyscyplinarne, położyć nacisk na podejścia komplementarne [...] problemy łączą dzisiaj dyscypliny, a nie metodologie" (E. Domańska, Jakiej metodologii potrzebuje wspótczesna humanistyka?, „Teksty Drugie” 2010, nr 1-2, s. 48). Wydaje się jednak, że uzyskanie efektu komplementarności (zamiast np. redundancji czy wzajemnego wykluczenia) wymaga działań transdziedzinowych.

${ }^{12}$ E. Domańska, „Zwrot performatywny” we wspótczesnej humanistyce, „Teksty Drugie” 2007 , nr 5, s. 51.

${ }^{13}$ Tamże, s. 55-57. 
prezentował Fryderyk Nietzsche ${ }^{14}$ ) i miejsce utrwalenia wniosków ustępuje miejsca tekstowi - laboratorium, które jest miejscem eksperymentu, ale i podmiotem sprawczym. Tekst w przestrzeni humanistyki to - jak podkreśla Ryszard Nycz - także „[...] zakumulowany w nim proces [...] tworzenia, poznawania, badania, oraz aktywowane $\mathrm{w}$ toku tego procesu środowisko warsztatowo-dziedzinowe i kulturowo-doświadczeniowe [...]" ${ }^{15}$. Kategoria paradygmatu rozumianego jako istniejący model, zbiór akceptowanych pojęć i teorii zastapiona zostaje kategoria paradygmatu'rozumianego jako tworzenie nowych pojęć i wydobywanie teorii z analizy porównawczej studiów przypadków oraz potrzeba metodologii, która uczy, jak to robić ${ }^{16}$. Paradygmat ten tworzą wskazane przez Domańską i Nycza (inspirowane m.in. pracami Michela Foucaulta, Gilles'a Deleuze'a, Patricka Joyce'a, Bruna Latoura, Clifforda Geertza) zmiany w sposobie myślenia w/o humanistyce dowodzące obecności efektu retorycznego na poziomie myślenia dziedzinowego.

Jednocześnie za paradygmat' można uznać ujęte w teorii Kuhna przekształcenie paradygmatu w wyniku anomalii, która w tym przypadku byłaby efektem zmian w przedmiocie badań - nasilającej się hybrydyzacji tekstów - jednoczesnego zakotwiczania ich w różnych sytuacjach komunikacyjnych. Zmieszanie form gatunkowych w myśleniu o tekście jest bowiem następstwem łączenia w tekstach będących przedmiotem odniesienia cech przynależnych do różnych form gatunkowych. Jest więc efektem dążenia do wytworzenia metody badań możliwie najbardziej adekwatnej do przedmiotu. Transdziedzinowość jest zatem następstwem transdyskursywności, która, choć we współczesnych utworach artystycznych przyjmuje formę szczególnie radykalna - hybrydyczna (by przywołać tu Dom z liści Marka Z. Danielewskiego), istnieje od dawna. O transgresji dyskursywności można bowiem mówić również wówczas, gdy w danym dyskursie pojawiają się w sposób wyraźny cechy, które stanowią dominantę innego dyskursu (lub wręcz wyznaczaja jego istotę). I tak, odnajdując w poezji Cypriana Kamila Norwida, Zbigniewa Herberta czy Wisławy Szymborskiej pytania i refleksje charakterystyczne dla filozofii (np. dotyczące bytu, sensu istnienia, poznania) określamy ją jako filozoficzna. Odnajdując w filozofii Kierkegaarda struktury narracyjne, które dominują w literaturze, przypisujemy wypowiedzi filozofa walor literackości. Jednocześnie w przestrzeni badań nad relacjami, w jakie wchodzą te dyskursy (ze strony filozofii) stawiane

${ }^{14}$ Zob. omówienie zagadnienia w: M.P. Markowski, Nietzsche. Filozofia interpretacji, Kraków 2001, s. 228-230.

${ }^{15}$ R. Nycz, Kultura jako czasownik. Sondowanie nowej humanistyki, Warszawa 2017, s. 159. Zob. też przywoływany przez uczonego tekst B. Latour, Dajcie mi laboratorium, a poruszę świat, przeł. K. Abriszewski, „Teksty Drugie” 2009, nr 1-2.

${ }^{16}$ E. Domańska, Jakiej metodologii..., s. 52-54. 
jest pytanie o to, „dlaczego podczas artykułowania oraz formułowania pojedynczej myśli, bądź też serii powiązanych myśli, jeden gatunek miałby być bardziej odpowiedni jako model reprezentacji niż inny?"17; formułowana jest teza, że myśl filozoficzna, jeśli ma zaistnieć, musi wyrażać się w jakiejś formie gatunkowej, przy czym forma ta ma wpływ na odczytanie sensu tej myśli ${ }^{18}$. Formami wypowiedzi zakotwiczonymi w obu dyskursach - zatem transdyskursywnymi są na przykład: dialog, wyznanie, soliloquium, opowiadanie, aforyzm czy esej ${ }^{19}$.

Transgresja zawsze funkcjonuje w ramach jakiegoś prawa, które ja umożliwia - pozwala na aplikowanie idei, zdobyczy jednej dziedziny do drugiej. Może ona być rezultatem świadomego zaproszenia - kiedy to dziedzina docelowa dokonuje importu idei, tendencji na własny grunt (np. przeniesienie dekonstrukcjonizmu z filozofii na grunt literatury i literaturoznawstwa czy architektury). Wówczas może pobudzać dziedziny do rozwoju. Ale może też przebiegać na drodze przemocy czy narzucenia, dokonując niechcianych przesunięć w sferze dominant i prowadząc do destrukcji dziedzin (np. wprowadzanie modelu zarządzania korporacyjnego, biznesowego do akademii czy szpitali sprawia, że prawda, poznanie, zdrowie przestają być celem i wartością nadrzędna, a stają się przedmiotem ekonomicznej obróbki i narzędziem finansowego zysku).

\section{Efekt retoryczny na poziomie dziedzin. Udział cyfrowości w eksplozji strukturalnej i tekście transdziedzinowym}

Sposób istnienia tekstu stanowi zwykle realizację cech dziedziny, którą dany tekst reprezentuje. Wyjście poza ten zakres inicjuje uzyskanie tego, co Łotman nazywa efektem retorycznym czy strukturą retoryczna, definiując ja jako „wprowadzenie do tekstu z zewnątrz immanentnie obcych mu zasad organizacji” ${ }^{20}$. Łotman daje przykład poetyki różnych nurtów awangardy, gdzie „znaczeniotwórczą zasadą tekstu w całości staje się zestawianie zasadniczo niezestawialnych ze sobą segmentów. Ich wzajemne przekodowa-

${ }^{17}$ J. Lavery, Gatunki filozoficzne a formy literackie: wprowadzenie nieco polemiczne, przeł. K. Kręglewska, „Tekstualia” 2019/1 (56), s. 15.

${ }^{18}$ Tamże.

${ }^{19}$ Przykładów realizacji tych form w przestrzeni filozofii dostarcza filozofia Platona, Marka Aureliusza, św. Augustyna, Michela Montaigne'a, Woltera, Fryderyka Nietzschego, Sørena Kierkegaarda i wielu innych.

${ }^{20}$ J. Łotman, Uniwersum umystu. Semiotyczna teoria kultury, przeł. B. Żyłko, Gdańsk 2008, s. 115. 
nie tworzy język wielokrotnych lektur, co odsłania nieoczekiwane rezerwy sensów”21. Inny przykład to „wtargnięcie języka prozy do poezji”"22.

Dziś przykłady wtargnięć, o których pisze Łotman, nie maja już tak wielkiej mocy retorycznej, a to dlatego, że poddane zostały oswojeniu, zaadaptowaniu. Stały się stałym elementem poetyki, a tym samym utraciły walor obcości, która jest warunkiem uzyskania efektu retorycznego. Obecnie, wtargnięcia w przestrzeń literackości, czy szerzej - sztuki, aby miały moc retoryczna, muszą dokonywać się z poziomu, który postrzegany jest przez literackość (i artystyczność) jako obcy, niepasujący do niej ${ }^{23}$. Wydaje się to niełatwe zwłaszcza w sytuacji, gdy działaniem artystycznym w dobie demokratyzacji życia społecznego rządzi zasada hybrydyzacji, czyniąca łączenie elementów różnych, niepasujących do siebie prawem sztuki. Sztuka, jako dziedzina życia społecznego, zdaje się w tej mierze realizować tezę ujętą w myśli filozoficzno-socjologicznej, która - jak pisze Marek Czyżewski znajduje swoje reprezentacje

[...] w semiotyce („,naturalizacja” tego, co „historyczne” u Rolanda Barthes'a), medioznawstwie (,hegemonia kulturowa” u Stuarta Halla), analizie dyskursu (,dyskurs dominujący" u Normana Fairclougha) i w socjologii (pojęcie doksy u Pierre'a Bourdieu). Wspólnym mianownikiem tych koncepcji jest pogląd, iż przekonania powszechnie uznawane za oczywiste same przez się (na przykład odnoszące się do ładu gospodarczego, społecznego czy obyczajowego) w istocie sa wyrazem panowania w kulturze określonego światopoglądu - lub odwrotnie rzecz ujmując: te przekonania, za którymi stoi sankcja panowania określonego światopoglądu, powszechnie są przyjmowane na mocy oczywistości ${ }^{24}$.

Wydawać by się mogło, że jeśli hybrydyzacja dostaje się w przestrzeń oczywistości, jeśli staje się zasada, zestawienie elementów niepasujących do siebie, obcych traci moc retoryczna. Nic bardziej mylnego. Problem tkwi w nieustannym oscylowaniu między konwencjonalizacją form hybrydycznych a ruchem ich ciagłego odświeżania. To, co skonwencjonalizowane, nie może dać efektu retorycznego, ale może go dać to, co nowe. Dlatego istota form hybrydycznych w przestrzeni sztuki jest ciagłe poszukiwanie nowych powiązań. Należy do nich inkorporowanie elementów należących do dziedzin dotychczas postrzeganych jako odległe czy wręcz niepasujące do siebie. Uzyskany w ten sposób efekt retoryczny kształtuje znaczenie tekstów

${ }^{21}$ Tamże, s. 108.

${ }^{22}$ Tamże, s. 115.

${ }^{23}$ Co więcej, literackość może być postrzegana jako tożsama z retorycznościa, gdyż, jak pisze Michał Rusinek, bierze się z rozbieżności znaczeń tekstu, jego wewnętrznej sprzeczności. Zob. M. Rusinek, Między retoryka a retorycznościa, Kraków 2003, s. 173.

${ }^{24}$ M. Czyżewski, Teorie dyskursu i dyskursy teorii, „Kultura i Społeczeństwo” 2013, nr 2, s. 7 . 
$\operatorname{transdziedzinowych.~Co~więcej,~wprawia~w~interakcje~cechy~formal-~}$ ne tekstów postrzegane dotąd jako reprezentujące odmienne dziedziny. Efekt retoryczny na poziomie transdziedzinowości prowadzi do eks p lo zji strukturaln ej, której efektem jest uruchomienie procesu kształtowania się nowych struktur tekstowych i cech gatunkowych.

Czynnikiem przyspieszającym ten proces są technologie cyfrowe. Umożliwiaja one po pierwsze transcendencję dziedzin na coraz bardziej zaskakującym poziomie, po drugie zaś produkowanie form powtarzalnych, wariantywnych, co staje się podstawą do wykuwania nowych gatunków. Wydaje się, że znajdujemy się obecnie na początkowym etapie tego procesu - na etapie dominacji eksplozji, która powoduje przede wszystkim pojawianie się coraz to nowych form tekstowych, struktur, cech gatunkowych jeszcze nieustabilizowanych. Dopiero spowolnienie dynamiki zmian nasili rozpoczęty już proces produkowania form powtarzalnych, które (jeśli zostaną wyodrębnione) mogą zostać opatrzone nazwą gatunkowa.

Wielość jednostkowych pomysłów tworzenia form tekstowych w interakcji różnych dziedzin skłania do pozostania przy kategorii tekstu transdziedzinowego. Za przykład takiego tekstu posłużyć może projekt „Symulakra”25. Wirtualna rzeźba umieszczona w listopadzie 2019 roku na fasadzie centrum handlowego przy pl. Unii Lubelskiej w Warszawie jest zaprojektowaną przez grupę „panGenerator” na zlecenie firmy „Screen Network” ruchomą formą artystyczną. Jej zmieniający się kształt zależy od natężenia ruchu ulicznego na przylegającej do placu ul. Puławskiej, ale też stopnia, w jakim osoby znajdujące się w okolicy ekranu korzystają z Internetu mobilnego. Wirtualny ruch generowany jest przez użytkowników smartfonów, co wprowadza element gry, której celem jest przyciagnięcie uwagi odbiorców i zaangażowanie ich w projekt (kreacja wiąże się tu z działaniem reklamowym). Zmiana w formie rzeźby może być też inicjowana przez użytkowników bezpośrednio za pomocą mobilnej strony internetowej symulacra.com. Widoczna na ogromnym ekranie ledowym bryła znajduje się w procesie nieustannego tworzenia się, przekształcania, cyfrowego „rzeźbienia”. Jest dziełem w ruchu, które konstytuowane jest w sposób zarówno intencjonalny i świadomy, jak i przypadkowy; w którego tworzeniu uczestniczą na równi ludzie (pomysłodawcy, programiści, użytkownicy środowiska cyfrowego), jak i byty nie-ludzkie (ruch uliczny, programy komputerowe i szerzej technologie cyfrowe). Zamysł artystyczny wskazuje na istotę tworów człowieka - jedno-

${ }^{25}$ Cyfrowa rzeźba w przestrzeni miejskiej od Screen Network i panGenerator, Wirtualnemedia.pl, 4.11.2019, <https://www.wirtualnemedia.pl/artykul/cyfrowa-rzezba-w-przestrzeni-miejskiej-symulakra-screen-network-i-pangenerator> [dostęp: 3.02.2021]; SYMULAKRAa digital sculpture in public space shaped by city traffic and data, <https://www.facebook.com/ pangenerator/videos/488083761793981/?v=488083761793981> [dostęp: 15.03.2020]. 
cześnie przypadkowych i genialnie zaplanowanych; nietrwałych i żywotnych; intencjonalnie oddzielających się od natury, a przy tym nieuchronnie, za sprawa swych cech, z nią związanych. Tym, co uruchamia nowe pokłady sensu, jest działanie metaforyczne oparte na transcendencji pól konotacyjnych elementów reprezentujących różne dziedziny życia społecznego: sztuki, cyfrowych technologii, ruchu ulicznego, zdalnej komunikacji. Zmieniający się kształt rzeźby oparty jest na ruchu, będącym efektem interakcji form ruchu - ruchu nieustannej zmiany w przestrzeni sztuki i technologii, mobilności ludzi, ruchu w świecie komunikacji cyfrowej, ruchu ulicznego, ruchu powodowania zmian w otaczającej nas rzeczywistości i wytworach człowieka. Nadto akt uruchamiania projekcji o stałych porach implikuje powtarzalność w czasie analogicznych form kreacji, cykliczność istnienia.

W jednym utworze przecinają się i spotykają elementy należące do różnych dyskursów i dziedzin. Ich spotkanie możliwe jest dzięki ruchowi, który obecny w różnych formach i na różnych poziomach kreacji, jest elementem wspólnym umożliwiającym jakąkolwiek zmianę w sferze sztuki, technologii, idei, ale i w świecie natury. Ruch jest koniecznym, choć często niezauważalnym warunkiem każdego działania - także retorycznego i także na poziomie, na którym w interakcję wchodzą elementy, własności zwyczajowo stawiane dotychczas po stronie tego, co biologiczne (naturalne) i nie-biologiczne (techniczne, cywilizacyjne).

Ruch łączenia, przecinania, wprawiania w interakcje elementów różnodziedzinowych w przypadku projektu „Symulakra” uwidocznia się też w zręcznym powiązaniu sztuki i techniki z reklamą i myślą filozoficzno-socjologiczna. Dokonuje się tego za pośrednictwem idei jakości, doskonałości - doskonała, bo oryginalna sztuka, doskonała technologia ekranów ledowych możliwe są dzięki konkretnej firmie, która zajmuje się wdrażaniem kampanii reklamowych z wykorzystaniem wielkoformatowych ekranów ledowych i której hasłem przewodnim jest: „Konsument stał się mobilny, taka też powinna być reklama”. Dzięki tej doskonałości każdy element rzeczywistości odbierany jest jako bardziej realny, namacalny, naturalny, głębiej doświadczany niż rzeczywistość sama. Twórcy projektu materializują tym samym myśl Jeana Baudrillarda ${ }^{26}$, świadomie nawiązując do niej zresztą również w tytule instalacji. Paradoks polega na tym, że owa materializacja dokonuje się też (w sposób zapewne niezamierzony) na polu Baudrillardowskiej krytyki wytworów społeczeństwa konsumpcyjnego. Oto fortel, ironia, iluzja nie sa już wyłącznie atrybutami podmiotu, ale przechodzą w rzeczy, uruchamiając podwójność gry, w której nie tylko my gramy ze światem, ale i świat bawi się nami ${ }^{27}$.

${ }^{26}$ Zob. J. Baudrillard, Symulakry i symulacja, przeł. S. Królak, Warszawa 2005.

${ }^{27}$ J. Baudrillard, Rozmowy przed końcem. Rozmawia Philippe Petit, przeł. R. Lis, Warszawa 2001, s. 93-94. 
W spotkaniu różnych dziedzin: sztuki, technologii, biznesu, reklamy, myśli filozoficzno-socjologicznej, a tym samym rozmaitych form ludzkiej komunikacji, dominację w projekcie grupy „panGenerator” zdobywa dyskurs artystyczny, który zostaje wzmocniony, ale też który zyskuje nowy wymiar dzięki oddziaływaniu towarzyszących mu czynników. W innych projektach firmy „Screen Network” jawna dominacja przypada dyskursowi reklamy, która cyfrową estetyzację przekazu podporządkowuje nadrzędnym celom perswazyjnym. W tym przypadku cyfrowość wspiera transgresję, która przebiega w przeciwnym kierunku - oto reklamowość zostaje zakryta przez artyzm. Dokonuje się to, co Baudrillard nazywa wzajemnym uwikłaniem sztuki i banału ${ }^{28}$, promieniowaniem fascynacji, w którym „symulakry nie sa już symulakrami, [lecz] przeobrażają się [...] w fetysze [...]”29 i w którym świat staje się reklamą pełniącą funkcję pochłaniania i oszałamiania interlokutora ${ }^{30}$.

Jednym ze sposobów ujawniania się transgresji dziedzinowości jest przenikanie koncepcji, idei wytworzonych w ramach jednej dziedziny do innych oraz inspirowanie ich do kreowania reprezentacji koncepcji wytworzonych na jej polu. I tak na przykład wypracowana w filozofii Gilles'a Deleuze'a idea fałdy ${ }^{31}$ w latach dziewięćdziesiątych ubiegłego stulecia inspirowała rozwój architektury foldingu. Fałda, widziana przez Deleuze'a jako niepodzielna całość, w myśli i praktyce architektonicznej zainicjowała formowanie nurtu opozycyjnego wobec architektury dekonstrukcyjnej postrzeganej jako nieciagła, sprzecznościowa, oparta na transformacji i reorganizacji formy. Idea fałdowania, składania oznaczała dla Petera Eisenmana (ale też Daniela Libeskinda, Jeana Nouvela) możliwość kreowania przestrzeni w sposób ciagły i spójny, łagodzaccy konflikty, zacieśniający więź z obserwatorem, godzący architekturę i naturę, a przy tym umożliwiajacy podmiotowi dotarcie $\mathrm{w}$ jednym spojrzeniu do różnych, niedostrzegalnych w innych, dotychczasowych konstrukcjach architektonicznych elementów przestrzeni, aspektów budowli ${ }^{32}$. W projektach Eisenmana, takich jak Aronoff Center for Design and Art na Uniwersytecie Ohio (Stany Zjednoczone, 1996); Miasto Kultury Galicji - centrum kultury w Santiago de Compostela (Hiszpania, 1999); Max Reinhardt Haus w Berlinie (Niemcy, 1993) dominuje idea ciagłości, przejścia z jednego elementu na inny wewnątrz konstrukcji przy jednocze-

${ }^{28}$ J. Baudrillard, Spisek sztuki. Iluzje $i$ deziluzje estetyczne $z$ dodatkiem wywiadów o „Spisku sztuki”, przedmowa S. Lotringer, przeł. S. Królak, Warszawa 2006, s. 105-106.

${ }^{29}$ Tamże, s. 60-61.

30 Tamże, s. 61.

${ }^{31}$ Zob. G. Deleuze, Fałda. Leibniz a barok, przeł. M. Janik, S. Królak, Warszawa 2014.

${ }^{32}$ Zob. M. Tobolczyk, Teoria architektury foldingu, [w:] tejże, Architektura wspótczesna. Geneza i charakterystyka wiodacych nurtów, Warszawa 2017, s. 304-314. 
snym wizualnym dostępie do tych powiązań. Towarzyszą jej idea wiązania projektu z kontekstem obiektu, topografią terenu oraz łączenia ruchu i zdarzeniowości angażującej widza i uczestnika tej przestrzeni z konieczną statycznością obiektu. Transdziedzinowość idei fałdy to nie tylko transgresja w przestrzeń architektury idei filozoficznej Deleuze'a, ale również, za jej pośrednictwem, transgresja w sferę innych dziedzin nauki: geometrii, fizyki, biologii czy psychologii - nauk, które myśl filozofa angażowała. To wreszcie transgresja w sferę technologii cyfrowych, cyfrowego projektowania, które owo łączenie, składanie elementów istotowo różnych w niepodzielną całość czyni czymś nie tylko możliwym, ale wręcz naturalnym.

W przypadku transdziedzinowości efekt retoryczny uzyskiwany jest na innym niż u Łotmana poziomie - nie w ramach jednej dziedziny, ale między dziedzinami. Elementy postrzegane jako charakterystyczne dla tekstów jednej dziedziny przenikają w przestrzeń tekstów reprezentujących inną dziedzinę. Efektem działań transdziedzinowych jest tworzenie tekstów, w których elementy różnych dziedzin dostaja się w pole wzajemnych oddziaływań, które zmieniają ich dotychczasową istotę. Nowo powstałe teksty nie mieszczą się już w zakresie dotychczasowych dziedzin, ale stają się tekstami transdziedzinowymi. Znaczenia i pola konotacyjne transponowanych elementów jednej dziedziny wchodzą w interakcję ze znaczeniami i polami konotacyjnymi dziedziny docelowej, tworząc nowe jakości znaczeniowe / nowe byty. Dochodzi do naruszenia stałości, stabilności dziedzin, do działania w jednej dziedzinie narzędziami innej, przenoszenia i nakładania kategorii, kątów widzenia jednej dziedziny na inna. Naruszenie, rozsadzanie, działanie, przenoszenie, nakładanie, przekład ${ }^{33}$ - to rzeczowniki konotujące ruch, który leży u podstaw zarówno transdziedzinowości, jak i retoryczności.

Powtarzalność analogicznych transferów, transcendencji pozwala na wyodrębnienie organizujących je zasad - struktur, które zyskują status pojęć. To moment, w którym działanie transdziedzinowe może skutkować powstaniem nowej dziedziny (czy nowego kierunku w jej ramach). Działanie metaforyczne zostaje unieruchomione, efekt retoryczny spełnia swą funkcję - wytworzenia nowych form strukturalnych - nowych sposobów kształtowania znaczeń w kulturze człowieka.

Ruch transgresji dziedzinowości jest formą myślenia, która by móc zaistnieć $\mathrm{w}$ przestrzeni społecznej, musi być uzewnętrzniona zgodnie ze sformułowaną przez Charlesa Sandersa Peirce’a zasadą głosząca, że „każda forma myślenia musi ucieleśniać się w pewnej formie wyrazu lub pozostać

${ }^{33}$ Jak pisze Paul de Man: „[...] ruch jest przejściem, a przejście jest przekładem; przekład znów oznacza ruch, nakłada ruch na ruch". P. de Man, Ideologia estetyczna, A. Przybysławski, A. Warmiński, Gdańsk 2000, s. 50. 
nieznaną"34. Ucieleśnienie transdziedzinowości oznacza konieczność nawet nie tyle łączenia różnych form znaków, co wręcz ich przemodelowania. Skoro bowiem transdziedzinowość oparta jest na działaniu metaforycznym, ruch transcendencji wiąże się w sposób konieczny z przemodelowaniem dziedzin, a w konsekwencji reprezentujących je tekstów i leżących u ich podstaw znaków. Bez wspólnoty znaków transcendencja cech jest ograniczona do jednostkowych przypadków lub ma charakter metaforyczny (jak w przypadku plastyczności, malarskości czy muzyczności opisu literackiego). Rozwiązania tego problemu dostarcza technologia cyfrowa.

Tym, co wspiera, a może wręcz w pełni umożliwia transcendencję tekstów oraz dziedzin, których te teksty są reprezentacjami, jest rozwój technologii cyfrowych, które znoszą jeden z ważniejszych elementów różnicujących teksty i dziedziny - konstytuującą teksturę materię znaku. Znak ${ }^{35}$, nadal zróżnicowany $\mathrm{w}$ warstwie wyrażania, ma w przestrzeni cyfrowej tę samą materię, co sprawia, że warstwa przedstawień jednych znaków może przenikać w warstwę przedstawień innych, modyfikując ją (doskonałego przykładu w sferze literatury dostarczaja ikonizowane, ruchome, zmieniające swój kształt, barwę, udźwiękowione litery i wyrazy). Wydaje się to szczególnie ważne w przypadku dziedzin sztuki, gdzie tekstura pełni kluczową rolę w kreowaniu znaczeń estetycznych, ale i różnicowaniu tych dziedzin oraz oddzielaniu ich od tego, co zewnętrzne. Tymczasem technologie cyfrowe likwidują bariery materiałowe między dziedzinami. Proponują teksturę, w której różnice semiotyczne sztuk - zakotwiczone w ich ontyczności, ale warunkowane także ich materia, stają się w znacznej mierze sprawą wyboru stylistycznego. Tak jest np. w literaturze cyfrowej, która zachowuje zasadę bycia sztuką słowa (to cecha ontyczna literatury), ale znaczenia artystyczne kształtuje nie tylko w sferze języka jako systemu znaków umownych, lecz również w sferze modelowania aspektu dźwiękowego i graficznego zapisu. Znaczenia artystyczne kreowane sa w interakcji słowa jako znaku arbitralnego i słowa jako znaku graficznego - ruchomego, przekształcanego na oczach odbiorcy, udźwiękowionego, a w efekcie tych wszystkich zmian, animizowanego i antropomorfizowanego.

Słowo literackie jest modelowane ruchem charakterystycznym dla znaków innych dziedzin sztuki - filmu, animacji - na znaczenie mają wpływ zmieniający się kształt słowa, jego ruch, które dodatkowo animizują a często i personifikują warstwę słowną. Wartość znaczeniotwórczą (symboliczna, impresywna, ekspresywna) mają barwa piśmiennego znaku słownego, któ-

${ }^{34}$ Cyt. za: S. Tokariew, Charles Sanders Peirce. Między logika a metafizyka, Kraków 2017, s. 167.

${ }^{35}$ Znak rozumiany jest tu zgodnie z teorią znaku cyfrowego sformułowaną w: E. Szczęsna, Cyfrowa semiopoetyka, Warszawa 2018, s. 91-121. 
ra nasyca je ikonicznościa, oraz powiązanie słowa graficznego z dźwiękiem, który konotuje muzyczność. Reinterpretowanie znaków jednej dziedziny sztuki znakami innej jest namacalnym efektem ruchu transcendencji, jaki dokonuje się dzięki tej samej materii znaków cyfrowych reprezentujących różne dziedziny. Ruch ten pozwala na nakładanie konotacji związanych z jedną dziedziną na inna, ingerowanie w sposób istnienia semiosfer uznawany dotąd za właściwy danej sztuce. Za przykład posłużyć tu mogą takie utwory, jak Faith ${ }^{36}$ Roberta Kendalla, Młodość 1861 liter później ${ }^{37}$ Leszka Onaka, Klikam ${ }^{38}$ Katarzyny Giełżyńskiej, Powieki ${ }^{39}$ oraz Ars poetica ${ }^{40}$ Zeno- $^{2}$ na Fajfera i wiele innych. Oto ruchomość liter i słów jako znaków graficznych, zmiany ich kształtu, barwy, przemieszczanie się, pojawianie się i znikanie w tekście na oczach odbiorcy zmienia status słowa literackiego jako znaku arbitralnego ${ }^{41}$. Zmienia też status literackości, która za pośrednictwem ikonizowanego, ruchomego słowa twórczo przetwarza formy nieliterackie, charakterystyczne dla innych dziedzin. Efektem tych przetworzeń są figury semiotyczne - w szczególności figury ruchu, które współtworzą znaczenia lub są ważnym źródłem impulsów znaczeniotwórczych - mają znaczacy wpływ na znaczenia konstruowane przez odbiorce.. W odniesieniu do transdziedzinowości warto dodać, że ruch ten pozwala na wkroczenie sfery denotacji i konotacji związanych z jedną dziedzina sztuki do innej, i to tak, że przeobrażeniu ulega sfera denotacji i konotacji tworów innej dziedziny sztuki. W efekcie zmienia się rozumienie tej dziedziny, to, co Peirce nazywa interpretantem, określając go jako „przyszłą pamięć poznania”:

Człowiek oznacza (denotes) wszystko, co jest przedmiotem jego uwagi w danym momencie; znaczy (connotes) wszystko, co wie lub czuje względem tego przedmiotu, jest wcieleniem tej formy lub cechy; jego interpretantem (interpretant) jest przyszła pamięć tego poznania, jego przyszłe ja, inna osoba, do której się zwraca, zdanie, które napisze lub dziecko, które spłodzi ${ }^{42}$.

Wkraczanie jednej dziedziny do innej za pośrednictwem warstwy wyrażania dotyczy nie tylko artystycznego wyzyskania warstwy przedstawień charakterystycznej dla innych sztuk, ale również obecnych w przestrzeni pozaartystycznej form gatunkowych i dyskursywnych. I tak np. w Strings ${ }^{43}$

\footnotetext{
$36<$ https://collection.eliterature.org/1/works/kendall_faith.html> [dostęp: 15.03.2020].

$37<$ http://techsty.art.pl/m10/mlodosc_1861_liter_pozniej/> [dostęp: 15.03.2020].

$38<$ https://vimeo.com/15657793> [dostęp: 15.03.2020].

${ }^{39}$ Z. Fajfer, Powieki, Szczecin-Bezrzecze 2013 (książka + CD).

$40<$ http://www.techsty.art.pl/magazyn3/fajfer/Ars_poetica_polish.html> [dostęp:
} 15.03.2020].

${ }^{41}$ Zob. analizy tych utworów w: E. Szczęsna, Cyfrowa semiopoetyka...

${ }^{42}$ Cyt. za: S. Tokariew, dz. cyt., s. 71.

${ }^{43}<$ https://collection.eliterature.org/1/works/waber_strings.html> [dostęp: 15.03.2020]. 
Dana Wabera w sposobach przekształcania się słów wykorzystywane są konotacje związane z zabawą w przeciaganie liny (dawniej dyscypliną sportowa) czy rebusem, natomiast w Popiele $i$ diamencie ${ }^{44}$ Agnieszki Słodownik, Michała Danielewicza i Michała Szoty wyzyskiwana jest konwencja gry paragrafowej.

Kształtowanie znaczeń artystycznych w procesie metaforycznego zderzania elementów różnych dziedzin sztuki, ale i nie sztuki wpisuje się w istotę cyfrowego działania tekstowego i dyskursywnego, nie jest zdarzeniem jednorazowym, ale techniką i zasadą tego środowiska. Dotyczy zresztą nie tylko literatury, ale i innych dziedzin sztuki, jak choćby sztuk plastycznych czy filmu. I tak, The nest of time ${ }^{45}$ Adama Martinakisa jest przykładem cyfrowej rzeźby, w której transgresja cyfrowości w przestrzeń rzeźby (i odwrotnie) zmienia istotę tej ostatniej - przekształca w byt niematerialny, ruchomy, zmieniający się na oczach odbiorcy - wręcz unarracyjniony. Zmieniający się kształt, przedstawienia bytów ludzkich, przechodzace łagodnie z jednego w drugi, z prostych w coraz bardziej złożone tworzą opowieść rozwijaną na prawach metonimii i asocjacji. Moc znaczeniotwórczą zyskują cyfrowe przekształcenia przestrzennych wyglądów, które modyfikują też istotę rzeźby jako formy sztuki.

Przykładów udziału cyfrowości w kształtowaniu tekstów transdziedzinowych dostarczają też narracyjne gry wideo ${ }^{46}$ (np. wyprodukowany w 2019 roku Telling Lies Sama Barlowa i Furiousa Bee), różne formy obecności filmu w grach ${ }^{47}$ czy gier w filmach. Za przykład tego ostatniego zjawiska moga posłużyć filmy interaktywne ${ }^{48}$. Są to np. powstałe w 2020 roku The Complex w reżyserii Paula Raschida, The Insider w reżyserii Michaela

${ }^{44}<\mathrm{https}: / /$ www.slodownik.com/popidiament-> [dostęp: 15.03.2020].

${ }^{45}<$ https://vimeo.com/240683811> [dostęp: 15.03.2020].

${ }^{46}$ Zob. np. B. Perron, Genre Profile: Interactive Movies, [w:] The Video Game Explosion: A History from PONG to Playstation and Beyond, red. M.J.P. Wolf, Westport-London 2008; P. Kubiński, Cyfrowe światoopowieści. Narracyjność gier wideo, [w:] Narratologia transmedialna. Teorie, praktyki, wyzwania, red. K. Kaczmarczyk, Kraków 2017.

${ }^{47}$ Sposoby istnienia środków filmowych w grach wideo były przedmiotem rozprawy doktorskiej Joanny Sikorskiej, Gra w film. Funkcjonowanie środków filmowego wyrazu w grach wideo (Uniwersytet im. Adama Mickiewicza w Poznaniu, 2019).

${ }^{48}$ Zob. np. R.W. Kluszczyński, U poczqtków historii filmu interaktywnego (Jeffrey ShawLuc Courchesne - Grahame Weinbren), „Postscriptum Polonistyczne” 2014/2 (14); tegoż, Kino interaktywne - porzadkowanie pola, [w:] Paradygmaty wspótczesnego kina, red. R.W. Kluszczyński, T. Kłys, N. Korczarowska-Różycka, Łódź 2015, s. 41-74; M. Filiciak, Hybrydyzacja technologiczna - machinima i interaktywne filmy, [w:] tegoż, Media, wersja beta. Film i telewizja w czasach gier komputerowych i internetu, Gdańsk 2013; A. Zwiefka, Gdzie jest Autor? Kilka stów o interaktywnych filmach dokumentalnych, „Pleigraf. Kwartalnik Akademii Polskiego Filmu" 2017/3; K. Kopczyński, Interaktywny film dokumentalny - historia i perspektywy rozwoju, „Media - Kultura - Komunikacja Społeczna” 2017, nr 13. 
Manna, proponujący pięć różnych zakończeń akcji, pochodzący z 2017 roku Mosaic w reżyserii Stevena Soderbergha, którego aplikacja mobilna pozwala m.in. na wybór perspektywy oglądu zdarzeń, czy wyemitowany w 2018 roku interaktywny odcinek serialu Black Mirror: Bandersnatch w reżyserii Davida Slade'a.

Akcja Bandersnatch umieszczona w latach osiemdziesiątych ubiegłego stulecia opowiada o młodym programiście, który zostaje zatrudniony w firmie projektującej gry wideo. Bohater, pracujacc nad utworem, w którym to gracz decydować ma o biegu zdarzeń w świecie przedstawionym, sam staje się częścia gry. Oto bowiem co jakiś czas akcja filmu jest zatrzymywana, a na ekranie pojawiaja się dwie opcje, z których widz ma dokonać wyboru w określonym czasie. Wybory, na początku niewinne (np. dotyczące tego, jakie płatki śniadaniowe ma zjeść bohater), stopniowo nabierają wagi - zaczynają decydować o losach i życiu bohaterów.

Interaktywność przekształca widza w użytkownika, czyniąc jego działania integralnym składnikiem tekstu; w strukturę filmu fabularnego włączone zostają elementy strukturalne gry wideo. Zatrzymywanie akcji i proponowanie wyboru kolejnego zdarzenia wprowadzają narrację alternatywną - bieg wypadków może być różny, za każdym kolejnym oglądaniem filmu realizowany przez widza inaczej (przy czym czas trwania utworu jest taki sam). Najistotniejsze jednak jest artystyczne wyzyskanie działania użytkownika - wpisanie go w fabułę utworu i w doświadczenie bohatera. Oto bowiem młody programista coraz wyraźniej doświadcza tego, że ktoś z zewnątrz wpływa na jego decyzje, że nie decyduje sam o swoim losie. Jako odbiorcy filmu widzimy, jak bohater zmaga się ze swoim ciałem, próbuje powstrzymać działania, które wybraliśmy jako użytkownicy (np. zaniechać zalania kawą klawiatury); usiłuje walczyć z narzucanymi mu czynami, którym ostatecznie i tak musi ulec. Świadomy obecności siły zewnętrznej, która nim kieruje, próbuje za pośrednictwem komputera nawiązać z nami (widzami-graczami) kontakt.

W utworze jest też trzeci poziom gry. Dotyczy on nas - widzów, którzy stajemy się narzędziem w rękach systemu komunikacyjnego obligującego nas do nowej roli, przekształcającego widzów w użytkowników filmowego świata - uczestników i sprawców narracji alternatywnej.

Black Mirror: Bandersnatch jest filmem, który na pierwszy rzut oka zdaje się rezygnować z medialnej i gatunkowej integralności, skoro zostaje ona rozsadzona przez wprowadzenie elementów struktury gry wideo. W istocie jednak szybko odsłania dominację filmowości, która czyni z growości chwyt artystyczny, włączając działania użytkownika w fabułę filmu. Utwór nieustannie balansuje między przetworzeniem gatunku filmowego - 
sugerowaniem formy hybrydycznej, łączącej film fabularny z grą wideo, a artystycznym użyciem tej ostatniej.

Film Davida Slade’a jest również przykładem ingerencji cyfrowości w ontyczność form dyskursywnych. Nie chodzi bowiem wyłącznie o przetworzenia dokonujące się w ramach gatunków, ale też o transformacje w sferze tego, co jest ważnym wyznacznikiem danej sztuki. W filmie, w którym widz staje się graczem, przetworzeniu ulegają relacje komunikacyjne stanowiące o specyfice sztuki filmowej. Odbiorca-widz zostaje zastapiony odbiorca-sprawca. Świat fikcji nie jest już wyłącznie przedstawiany - dany odbiorcy do interpretacji, ale również przez niego współwystawiany. Zyskuje zatem nowy status ontyczny. Zmienia się też status interpretacji, która z aktywności zewnętrznej wobec warstwy przedstawień tekstu przemieszcza się w stronę jej przekształcania. Interpretacja staje się częścią tekstu także jako czynnik kształtowania tekstury.

Wprawienie w interakcję elementów formalnych reprezentujących odmienne dziedziny prowadzi do eksplozji strukturalnej, która skutkuje kreowaniem tekstów transdziedzinowych opartych na nowych strukturach tekstowych. W procesie tworzenia wielu tekstowych reprezentacji określonej formy tekstu transdziedzinowego dochodzi do wykuwania nowych form gatunkowych, których ugruntowana pozycja znajduje odzwierciedlenie w nazwach gatunkowych.

\section{Wnioski}

- Rozwój kultury dokonuje się w procesie nieustannego, naprzemiennego ustanawiania granic między różnymi dyskursami i różnymi dziedzinami oraz przekraczania ich. Siłę kulturotwórczą ujawniają zwłaszcza procesy transgresji.

- Relacje inter- są relacjami, w których dziedziny się konfrontuja, zachowując swoją osobność, niezależność. Relacje te lokują się po stronie myślenia kategoriami dziedzinowości, podkreślania ważności ustanowionych paradygmatów, jednocześnie są pierwszym przejawem procesu przekraczania granic dziedzin. Relacje inter- są oparte na myśleniu porównawczym. W procesie trans- zatarciu lub wręcz zniesieniu ulegaja granice między dziedzinami, dochodzi do mieszania się dziedzin, które traca swoją niezależność. Proces ten lokuje się po stronie myślenia kategoriami laboratorium, sprawstwa, powodowania nowych, nieprzewidzianych wcześniej jakości. Procesem trans- rządzi myślenie metaforyczne.

- To, że prefiksy inter-i trans- sa reprezentacjami (realizacją na poziomie makro) myślenia porównawczego i metaforycznego jest gwarancją ich 
równouprawnionego współistnienia w kulturze, ontycznej nieredukowalności, choć moga łączyć się z różnymi aspektami kultury - tekstualnościa, semiotycznościa, dyskursywnościa, dziedzinowościa; moga w procesie rozwoju kultury kształtować tendencje wysuwające się na plan pierwszy lub schodzace na plan dalszy.

- Transcendencja dziedzinowości wiąże się z przekształcaniem zarówno tego, co wkracza w cudzą przestrzeń, jak i tego, co ją przyjmuje (dziedziny docelowej). Stopień modyfikacji obu podmiotów może być różny i zależy od ich siły, ale też kontekstu kultury. W przypadku gdy dziedzina docelowa dominuje nad tym, co wkracza w jej rejony, dochodzi zwykle do przystosowania nowej idei (tendencji, mody) do własnych potrzeb - wbudowania jej we własną tkankę, wpisania we własne tendencje rozwojowe. Dziedzina docelowa staje się użytkownikiem tendencji innodziedzinowych. Może jednak być też i tak, że w procesie transgresji dziedzina docelowa okazuje się słabsza niż napływające tendencje, które narzucają jej swoje prawa i przekształcają ja.

- Transcendencja dziedzinowości jest jednocześnie następstwem i przyczyną transcendencji dyskursywności i transcendencji tekstualnej.

- Czynnikami intensyfikujacymi transdziedzinowość (i transtekstualność) są demokratyzacja życia społecznego oraz cyfrowość (znak cyfrowy zniósł granice między artefaktami kultury w środowisku cyfrowym; umożliwił swobodne przetwarzanie, łączenie cech tekstów różnodyskursywnych, tworzenie projektów transdziedzinowych), zaangażowanie w tekst działań użytkownika; co na poziomie dziedzinowym zaowocowało sprawstwem.

- Transcendencja dziedzinowości daje efekt retoryczny na poziomie ponadtekstowym i ponadgatunkowym. Efekt ten powstaje w wyniku przenikania cech, procedur, specyfiki jednych dziedzin w rejony innych, mieszania ich, wprawiania w interakcję pól znaczeniowych wytwarzanych przez dziedziny uznawane dotąd za nieprzystajace do siebie. Proces ten zyskuje niespotykaną wcześniej dynamikę dzięki technologiom cyfrowym. Dochodzi mianowicie do eksplozji strukturalnej - gwałtownego uwolnienia się energii formotwórczej (a w następstwie i sensotwórczej) - tworzenia nowych jakości formalnych - nowych tekstów, które określam zbiorczą nazwą tekstów transdziedzinowych, nowych struktur tekstowych (np. figur semiotycznych - zwłaszcza figur ruchu czy narracji alternatywnej), wreszcie nowych gatunków.

- Kreowana narzędziami cyfrowymi transdziedzinowość zwłaszcza w przestrzeni sztuki ujawnia swój retoryczny charakter, stając się gwarantem trwania i rozwoju, czyniąc sztukę miejscem dialogu różnych dziedzin, które - jak ludzie - w izolacji, jeśli nie dziczeja, to z cała pewnościa milkna. 


\section{BIBLIOGRAFIA}

Barthes R., Teoria tekstu, przeł. A. Milecki, [w:] Wspótczesne teorie badań literackich za granica. Antologia, t. 4, cz. 2, red. H. Markiewicz, Kraków 1996.

Baudrillard J., Rozmowy przed końcem. Rozmawia Philippe Petit, przeł. R. Lis, Warszawa 2001.

Baudrillard J., Spisek sztuki. Iluzje i deziluzje estetyczne $z$ dodatkiem wywiadów o „Spisku sztuki”, przedmowa S. Lotringer, przeł. S. Królak, Warszawa 2006.

Baudrillard J., Symulakry i symulacja, przeł. S. Królak, Warszawa 2005.

Czyżewski M., Teorie dyskursu i dyskursy teorii, „Kultura i Społeczeństwo” 2013, nr 2.

Deleuze G., Fałda. Leibniz a barok, przeł. M. Janik, S. Królak, Warszawa 2014.

Domańska E., Jakiej metodologii potrzebuje wspótczesna humanistyka?, „Teksty Drugie” 2010, nr 1-2.

Domańska E., „Zwrot performatywny” we wspótczesnej humanistyce, „Teksty Drugie” 2007, nr 5.

Domańska I., Antropologia literatury - projekt interdyscyplinarny czy transdyscyplinarny, „Przegląd Kulturoznawczy” 2011, nr 1.

Dyskurs jako struktura i proces, red. T.A. van Dijk, przeł. G. Grochowski, Warszawa 2001.

Eco U., Dzieło otwarte. Forma i nieokreśloność w poetykach wspótczesnych, przeł. L. Eustachiewicz i in., Warszawa 2008.

Fajfer Z., Powieki, Szczecin-Bezrzecze 2013 (książka + CD).

Filiciak M., Hybrydyzacja technologiczna - machinima i interaktywne filmy, [w:] tegoż, Media, wersja beta. Film i telewizja $w$ czasach gier komputerowych $i$ internetu, Gdańsk 2013.

Geertz C., O gatunkach zmaconych (Nowe konfiguracje myśli społecznej), przeł. Z. Łapiński, [w:] Postmodernizm. Antologia przekładów, red. R. Nycz, Kraków 1997.

Kluszczyński R.W., Kino interaktywne - porzadkowanie pola, [w:] Paradygmaty wspótczesnego kina, red. R.W. Kluszczyński, T. Kłys, N. Korczarowska-Różycka, Łódź 2015.

Kluszczyński R.W., U poczqtków historii filmu interaktywnego (Jeffrey Shaw - Luc Courchesne - Grahame Weinbren), „Postscriptum Polonistyczne” 2014/2 (14).

Kopczyński K., Interaktywny film dokumentalny - historia i perspektywy rozwoju, „Media - Kultura - Komunikacja Społeczna” 2017, nr 13.

Kress G., Multimodality. A Social Semiotic Approach to Contemporary Communication, London-New York 2010.

Kress G., Leeuwen T. van, Multimodal Discourse. The Modes and Media of Contemporary Communication, London 2001.

Kubiński P., Cyfrowe światoopowieści. Narracyjność gier wideo, [w:] Narratologia transmedialna. Teorie, praktyki, wyzwania, red. K. Kaczmarczyk, Kraków 2017.

Kuhn T.S., Dwa bieguny, przeł., posłowiem opatrzył S. Amsterdamski, Warszawa 1985.

Kuhn T.S., Struktura rewolucji naukowych, przeł. H. Ostromęcka, Warszawa 2001.

Latour B., Dajcie mi laboratorium, a porusze świat, przeł. K. Abriszewski, „Teksty Drugie" 2009, nr 1-2.

Lavery J., Gatunki filozoficzne a formy literackie: wprowadzenie nieco polemiczne, przeł.

K. Kręglewska, „Tekstualia” 2019/1 (56).

Łotman J., Uniwersum umystu. Semiotyczna teoria kultury, przeł. B. Żyłko, Gdańsk 2008.

243 Transdziedzinowość - retoryczność - cyfryzacja 
Man P. de, Ideologia estetyczna, A. Przybysławski, A. Warmiński, Gdańsk 2000.

Markowski M.P., Nietzsche. Filozofia interpretacji, Kraków 2001.

Nicolescu B., Transdisciplinarity - Past, Present, and Future, [w:] Moving Worldviews Reshaping Sciences, Policies and Practices for Endogenous Sustainable Development, red. B. Haverkort, C. Reijntjes, Leusden 2007, s. 142-166, <http://basarab-nicolescu. fr/Docs_articles/TRANSDISCIPLINARITY-PAST-PRESENT-AND-FUTURE.pdf> [dostęp: 3.02.2021].

Nycz R., Kultura jako czasownik. Sondowanie nowej humanistyki, Warszawa 2017.

Nycz R., Możliwa historia literatury, „Teksty Drugie” 2011, nr 1-2.

Perron B., Genre Profile: Interactive Movies, [w:] The Video Game Explosion: A History from PONG to Playstation and Beyond, red. M.J.P. Wolf, Westport-London 2008.

Rusinek M., Między retorykq a retorycznościq, Kraków 2003.

Sikorska J., Gra w film. Funkcjonowanie środków filmowego wyrazu w grach wideo (rozprawa doktorska, Uniwersytet im. Adama Mickiewicza w Poznaniu, 2019).

Stownik języka polskiego, red. M. Szymczak, Warszawa 1988.

Systemowo-funkcjonalna analiza dyskursu, red. A. Duszak, G. Kowalski, Kraków 2013.

Szczęsna E., Cyfrowa semiopoetyka, Warszawa 2018.

Szczęsna E., Poetyka mediów. Polisemiotyczność, digitalizacja, reklama, Warszawa 2007.

Tobolczyk M., Teoria architektury foldingu, [w:] tejże, Architektura wspótczesna. Geneza i charakterystyka wiodacych nurtów, Warszawa 2017.

Tokariew S., Charles Sanders Peirce. Między logika a metafizyka, Kraków 2017, s. 167.

Ulicka D., Sub-, pre-, post-, inter-, czyli jak formy prefiksalne graja w teatrze literaturoznawczej mowy?, [w:] Przyszłość polonistyki. Koncepcje - rewizje-przemiany, red. A. Dziadek, K. Kłosiński, F. Mazurkiewicz, Katowice 2013.

Zeidler-Janiszewska A., Visual Culture Studies czy antropologicznie zorientowana Bildwissenschaft? O kierunkach zwrotu ikonicznego w naukach o kulturze, „Teksty Drugie" 2005, nr 4.

Zwiefka A., Gdzie jest Autor? Kilka słów o interaktywnych filmach dokumentalnych, „Pleigraf. Kwartalnik Akademii Polskiego Filmu” 2017/3. 